\title{
THE JUDICIAL REFORM ACT: HISTORY, ANALYSIS, AND COMMENT
}

\author{
John H. Holloman, III*
}

\section{INTRODUCTION}

On October I5, 1965, Senator Joseph D. Tydings announced on the Senate floor that his Subcommittee on Improvements in Judicial Machinery of the Committee on the Judiciary had initiated a comprehensive study of the federal courts and would soon begin hearings on a number of proposed reforms, including an alternate procedure for removal of federal judges found "unfit by reason of physical or mental incapacity, inefficiency, or corruption."1 On February 15, I966, the Tydings subcommittee began exploratory hearings on the subject of judicial fitness, concentrating on the experience and laws of the several states, with attention finally focusing on the New York Court on the Judiciary and the California Commission on Judicial Qualifications. Following a year of study, research, discussion, and analysis, the Judicial Reform Act was drafted and introduced by Senator Tydings on February 28, I968. ${ }^{2}$ Further hearings were held and the Act, with minor changes, was reintroduced in the Ninety-first Congress. ${ }^{3}$

The Judicial Reform Act consists of five titles, the first establishing a Commission on Judicial Disabilities and Tenure; the second relating to the retirement of judges; the third revising the judicial survivor annuity program; the fourth dealing with "conflicts of interest" and financial disclosure; the fifth providing district judge representation on the circuit councils, the appointment of court executives, and establishing an age limitation for promotion to chief judge. While each of these proposals is important and has as its objective the improvement of the administration of justice, the Commission on Judicial Disabilities and Tenure is by far the most significant, far-reaching, and controversial. As acknowledged by Senator Tydings, "The primary feature of the act, however, is the establishment of a permanent Commission on Disabilities and Tenure ...." It is therefore upon title I of the Judicial Reform Act that this article will focus.

To ascertain the legislative intent of the Act at this point is to understand the

* Chief Counsel and Staff Director, Committee on Judiciary, United States Senate.

1 III CoNG. REC. 27108 (1965) (remarks of Senator Tydings).

2S. 3055, goth Cong., 2d Sess. (1968). See II4 CoNG. Rec. 4558 (1968) (remarks of Senator Tydings).

${ }^{3}$ S. I506, 91st Cong., Ist Sess. (1969). See II5 Cong. Rec. S2732 (daily ed. March I2, 1969) (remarks of Senator Tydings).

'Hearings on S. 1506, The Judicial Reform Act, and Related Bills Before the Subcomm. on Improvements in Judicial Machinery of the Senate Comm. on the Judiciary, grst Cong., Ist Sess. 2 (1969). [hereinafter cited as 1969 Hearings]. 
intent of Senator Tydings, who is its author in fact as well as phrase, its principal sponsor and spokesman. A brilliant lawyer in his own right, Senator Tydings is an exceptionally effective advocate, an aggressive legislative leader and strategist with an enviable record of bills signed into law, including but not limited to acts affecting the federal courts. ${ }^{5}$ His intention is clear and unmistakable. It is to improve the administration of justice, enhance the prestige of the federal judiciary and secure public confidence in and support for the rule of law. Assuming its constitutionality, the principal question is whether it will accomplish the desired result, without sacrificing the time-honored independence of the federal judiciary.

In considering the Judicial Reform Act, we need to understand the genesis of the idea that federal judges can be removed from office, de facto or de jure, by means other than impeachment as well as the origin and evolution of the concept of a removal court or commission for this purpose. Since the past is prologue, we need to understand the motives of those who have advanced such proposals in the past, as well as the reasons others have attempted to remove federal judges by impeachment and other means. For while we know the honorable intentions and laudable objectives of those who propose the Commission on Judicial Disabilities and Tenure, we must attempt to ascertain for what purposes it might be used in other times, by other men, for different reasons and objectives.

In order to assess its chances of passage, the Judicial Reform Act must be considered in the context of the times and in the light of current events. Speeches on court reform by Chief Justice Warren received little attention only a few years ago. As recently as October I5, I965, Senator 'Tydings' speech on court reform and his subsequent hearings attracted little attention outside the bench and bar. The possibility that a commission for the removal of federal judges would be favorably received by Congress was distinctly remote. But in 1970 the subject of court reform in general and judicial discipline in particular has moved from the back pages to the front pages of our newspapers and to the covers of widely circulated magazines. ${ }^{b}$ In an occurrence unheard of several years ago, a recent speech on August 10, 1970, by the Chief Justice, to the American Bar Association on the state of the judiciary, was televised live to a national audience and reported on the front pages of every major paper. The same forces and events that have been responsible for this phenomenon have likewise contributed to the growing support for the Judicial Reform Act. As will be noted, a number of proposals contained in the Act have already passed the Senate as separate bills or incorporated in other legislation. A

\footnotetext{
' See, e.g., The Federal Magistrates Act, 28 U.S.C. $\$ \$ 63$ I-39 (Supp. III, I968); The Jury Selection and Service Act of 1968,28 U.S.C. $\$ \S \mathrm{I} 86 \mathrm{I}-69$ (Supp. III, I968); The Multidistrict Litigation Act, 28 U.S.C. $\$ \S$ I39I-I406 (I968); The Omnibus Judgeship Act of I968, 28 U.S.C. $\$ 44$ note (Supp. III, I968); The Omnibus Judgeship Act of 1970 , Pub. L. No. 91-272; The District of Columbia Court Reorganization Act of 1969 , Pub. L. No. 91-358.

${ }^{\circ}$ See, e.g., Main, Only Radical Reform Can Save the Courts, Fortune, Aug. I970, at III; Wittner, Logjam In Our Courts, Life, Aug. 7, 1970, at x8; N.Y. Times, Aug. 2, 1970, at I, col. 3.

${ }^{7}$ For text of Burger speech see U.S. News \& WordD Report, Aug. 24, r970, at 68.
} 
judicial reform commission has been enacted into law for the District of Columbia courts as part of the D.C. Crime Bill. And the very threat contained in title IV has prompted the Judicial Conference to hurried action on a number of related proposals. An understanding of the people, the forces, and events that have contributed to this present atmosphere is basic to a true understanding of the Act.

\section{HistoRY}

"[E]xperience has already shown that the impeachment [the Constitution] has provided is not even a scare-crow . ..." Thus Thomas Jefferson, having succeeded in repealing the infamous Judiciary Act of $\mathrm{r} \mathrm{or}^{9}$ and impeaching District Judge John Pickering of New Hampshire, ${ }^{10}$ expressed bitter frustration at his failure to impeach Associate Justice Samuel Chase, ${ }^{11}$ thus being thwarted in his purge of Federalists appointed under the original Judiciary Act of $1789 .{ }^{12}$ From the earliest days of the Republic, efforts have been made from time to time, for various reasons good and bad, without the executive, legislative, and judicial branches of government, to devise means and contrive theories to circumvent the use of the difficult impeachment process to effectuate, de jure or de facto, the removal of federal judges from office or the negation or dilution of their influence. Continued efforts have been made to amend the Constitution to change their tenure, as well as the method of appointment and removal. ${ }^{13}$ However, as adoption of these amendments has proven more difficult than the impeachment process itself, others have sought to accomplish the same results by simple statute and other means. From Jefferson's repeal of the

\footnotetext{
${ }^{8}$ Letter from Thomas Jefferson to Judge Spencer Roane, Sept. 6, I8rg, in XV ThE Wrutings of Thomas JefFerson $21_{3}$ (A. Bergh ed. 1907).

- See Kurland, The Constitution and the Tenure of Federal Judges: Some Notes from History, 36 U. CFI. L. REv. 665,678 ( $\mathrm{x} 969$ ): "No judicial test of this action was made. Following this success, the Jeffersonians sought to eliminate the Federalist judges who were holding office under the original judiciary act by bringing impeachment proceedings."

${ }^{0}$ See II G. Haynes, The Senate of the United States 849 (1938): "The politcial animus back of the Pickering impeachment was clear."

${ }^{11}$ See Blackmar, On the Removal of Judges: The Impeachment Trial of Samucl Chase, 48 J. AM. Jud. Soc'y 183 (1965).

12 "The failure to convict Chase on even one count was a major setback to the political plans of the Republicans." Dilliard, Samtel Chase, in I The Justices of the United States Supreme Court $7789-1969$, at 196 (Friedman \& Israel eds. 1969). "Everyone recognized that if the impeachment of Chasc resulted in his removal, this trial would be but the curtain-raiser to the trial of Chief Justice Marshall, whose recent decision in Marbury v. Madison had greatly affronted Jefferson." II Haynes, stipra note I0, at 851. "They were successful in the removal of Judge Pickering of New Hampshire, but this movement foundered when the impeachment of Mr. Justice Chase failed of conviction." Kurland, supra note 9, at 678 .

18 "Representative John Randolph of Virginia, who bore much of the blame for the collapse of the [Chase] prosecution, sought unsuccessfully, before the dust of battle had settled, to recoup by proposing a constitutional amendment providing that "The Judges of the Supreme Court and all other courts of the United States shall be removed from office by the President on the joint address of both Houses of Congress requesting the same." Dilliard, supra note 12, at 197. A more recent attempt was Senator Ervin's S.J. Res. r94, goth Cong., 2d Sess. (rg68).
} 
Judiciary Act of I8or, which abolished the courts and deprived the judges of their tenure, to Wilson's abolition of the Commerce Court, which retained the tenure of judges already appointed, these results were obtained under the power of Congress to create and abolish inferior courts. ${ }^{14}$ From Congressman Bingham's proposals in the Reconstruction Congress ${ }^{15}$ to President Roosevelt's court-packing plan in the Seventy-fifth Congress, ${ }^{18}$ legislation has been introduced to add additional judges to the federal judiciary for each judge having arrived at age seventy and not electing to retire.

Within the judicial branch itself, the influence of some judges has allegedly been diluted, for instance, by exclusion from three-judge courts or assignment to serve on stacked panels. ${ }^{17}$ Others have been pressured into retirement under threat of assignment to hardship posts and by various uses of section 332 of title 28 of the United States Code. ${ }^{18}$ One circuit stripped a district judge of all pending and future cases, citing this "housekeeping" or administrative authority. ${ }^{19}$

Yet it was not until 1930 that constitutional theorists conceived the idea that by simple statute " $[\tau]$ he federal bench should be authorized to remove its own unfit members." ${ }^{20}$ As stated by its proponent, "[T] he details of such schemes need not detain us; it is only meant to suggest the general idea of allowing the judiciary branch an opportunity to keep its own house in order."21 Convinced the Achilles' heel had been found in the concept of life tenure for federal judges, proponents were not long in supplying "the details of such schemes" in the court-packing atmosphere of the New Deal Congress. The first such legislation was introduced in the Senate on April 23, I936, in the form of Senate Bill 4527, providing for the establishment of a High Court for the Trial of Judicial Officers. ${ }^{22}$

Yet it would be in the House where the fight would be waged and the issue joined as to the desirability and constitutionality of such "schemes." The first real effort

\footnotetext{
${ }^{16}$ U.S. Const. art. I, $\S 8$, I9. See Kurland, supra note 9, at $68_{7}$ : "The Commerce Court was doomed. But the question remained whether the judges were to be deprived of their tenure. . . . The Senate version, preserving the judgeship, ultimately prevailed, so that the precedent of 1802 was not repeated."

${ }^{15}$ See Kurland, stipra note 9, at 678-83.

${ }^{10}$ See generally Leuchtenburg, The Origin of Franklin D. Roosevelt's "Court-packing" Plan, I966 Sup. CT. REv. 347. Hearings on S. 1392 Before the Senate Comm. on the Judiciary, 75th Cong., rst Sess., pts. I-4 (I937).

${ }^{17}$ See, e.g., Armstrong v. Board of Education, 323 F.2d 333, 358-6I (5th Cir. I963) (dissenting opinion).

${ }^{18}$ See, e.g., Hearings on S. 3055, The Judicial Reform Act, and Related Bills Before the Subcomm. on Improvements in Judicial Machinery of the Senate Comm. on the Judiciary, 9oth Cong., $2 \mathrm{~d}$ Sess., at 249-50 (rg68) (colloquy between Senator Tydings and Chief Judge Richard Chambers) [hereinafter cited as rg68 Hearings].

${ }^{10}$ Chandler v. Judicial Council, 398 U.S. 74 (1970).

${ }^{20}$ Shartel, Federal Judges-Appointment, Supervision, and Removal-Some Possibilities Under the Constitution, 28 Mrcr. L. REv. 870, 875 (1930).

${ }^{21} I d$.

${ }^{23}$ S. $4527,74^{\text {th }}$ Cong., $2 \mathrm{~d}$ Sess. (1936). The text of S. 4527 is also set out in Otis, $A$ Proposed Tribunal: Is It Constitutional?, 7 U. Kan. City L. REv. 3, IO-II (1938).
} 
to enact legislation of this nature began with the introduction of House Resolution 227r, known, as was its progeny in successive Congresses as the Sumners Bill for its able and determined advocate, Congressman Hatton Sumners, Chairman of the House Judiciary Committee. The Sumners Bill provided that upon receipt of a resolution of the House of Representatives alleging "reasonable ground for believing that the behavior" of a federal district judge "has been other than good behavior within the meaning of that term as used in section $x$ of article III of the Constitution" the "Chief Justice shall designate" three circuit judges, one of whom must be from the circuit of the accused judge. The bill further provided that the Attorney General bring a "civil action in such court to determine the right of such judge to remain in office." Upon determination of the court that "the behavior of the judge has been other than good behavior," the "judgment shall be that the judge is thereupon removed." Pending appeal to the Supreme Court, the judge was to be suspended from office with pay. ${ }^{23}$

The Sumners Bill received, in principle, the support of the Assembly of the American Bar Association meeting on September 29, 1937, in Kansas City. ${ }^{24}$ It passed the House the next year, but died in the Senate. ${ }^{25}$ Although the Sumners Bill, amended to include circuit judges, was defeated by the House in the Seventysixth Congress, ${ }^{26}$ it picked up additional support from the American Bar Association and the Judicial Conference of the United States. The American Bar Association, meeting in September r940, adopted a resolution favoring enactment of the Sumners $\mathrm{Bill}_{,}{ }^{27}$ and in October of 1940 the Judicial Conference, upon recommendation of a committee including Judge Learned Hand, approved the Sumners Bill as follows: "Assuming its constitutionality, as to which we express no opinion, we are in accord with the general purpose and approve in principle the provisions embodied in H.R. 9160."28 Thus reinforced, the Sumners Bill was reintroduced in the Seventy-seventh Congress, received editorial support from the American Bar Association Journal ${ }^{20}$ and a favorable opinion from Acting Attorney General Biddle, ${ }^{30}$ and passed the House on October 22, I94r. ${ }^{31}$ On November 26, 194r, hearings where held before a subcommittee of the Senate Judiciary Committee, chaired by Senator O'Mahoney of Wyoming, at which time Attorney General Biddle expanded his previous support. ${ }^{32}$ Associate Justice Jackson, following the course of the Judicial Council, supported the

\footnotetext{
${ }^{28}$ H.R. 227I, 75th Cong., Ist Sess. (I937). The text also appears in Otis, stipra note 22, at II-12.

2462 A.B.A. REP. 127 (1937).

25 See Kurland, stipra note 9, at 693.

${ }^{26} I d$.

${ }^{27} 65$ A.B.A. REP. 80 (I940).

${ }^{28}$ Judicial Conference of the United States, Proceedings 23 (1940).

${ }^{20} 27$ A.B.A.J. I63, 552 (I94T).

${ }^{30}$ Letter from Francis Biddle to Congressman Hatton W. Sumners, June 24, I941, in Hearings on H.R. 146 Before a Subcomm. of the Senate Comm. on the Judiciary, 77th Cong., rst Sess. 5-6 (194X) [hereinafter cited as $194 \mathrm{I}$ Hearings].

${ }^{a 1} 87$ Cong. Rec. 8 I68 (I94I).

${ }^{32}$ I94I Hearings, supra note 30 , at 3I-39.
} 
principle of the legislation while declining to discuss the constitutional issue. ${ }^{33}$ Yet this support notwithstanding, the Senate Judiciary Committee did not act and similar bills introduced by Sumners in the Seventy-eighth and Seventy-ninth Congresses went nowhere. ${ }^{34}$ Sumners was not a candidate for re-election in 1946, and the idea of a tribunal for the removal of federal judges would not be revived in Congress for nearly two decades.

Legislative initiative in the area of judicial removal then shifted to the states where the Court on the Judiciary, created by adoption of a constitutional amendment in New York in $1948{ }^{35}$ and the Commission on Judicial Qualifications adopted as an amendment to the California constitution in $1960,{ }^{36}$ have served as prototypes for an ever increasing number of states. This movement was undoubtedly pushed by increasing problems with the efficient administration of justice, impeachment trials in Florida ${ }^{37}$ and Oklahoma, ${ }^{38}$ and adoption in 1962 by the American Bar Association of a model judicial article for state constitutions. ${ }^{39}$ Later in I962, publication of $T$ he Corrupt Judge $e^{40}$ by Joseph Borkin once again focused national attention on the problems of dealing with corrupt judges through the impeachment process. Described as an "eye-opening shocker" 11 by Senator Kefauver, the book did prompt the introduction of several bills in the Congress dealing with financial disclosure and outside activities of federal judges. ${ }^{42}$ Close on the heels of the Borkin book, there appeared on May 2, Ig63, a prize-winning article in the Wall Street Journal by Jerry Landauer raising conflict of interest questions concerning extra-judicial activities of federal judges such as service on the boards of directors of banks and other profitmaking corporations. Adverse public reaction to the Landauer article was obviously responsible for the adoption by the Judicial Conference at its October 1963 meeting of a resolution forbidding justices and judges from serving as directors on the boards of profit-making corporations. ${ }^{43}$

Later in $\mathrm{r}_{963}$, public attention was focused on the legislative branch with the revelations in the Bobby Baker case. As Senator Keating noted, "It always seems to require prodding from some unfortunate experience of some kind to insure

\footnotetext{
${ }^{33} \mathrm{Id}$. at $25-3 \mathrm{r}$.

st Kurland, supra note 9 , at 693 .

${ }^{30}$ N.Y. Consr. art. VI, $\$ 9$, renumbered Sept. I, I962, as art. VI, $\$ 22$.

${ }^{30}$ CaL. Const. art. VI.

${ }^{37}$ See Dunn, Impeachment System Goes on Trial, Tampa Tribune, Jan. I9, I964, at 4g, col. I.

${ }^{38}$ See Harp, An Oklahoma View-The Discipline and Removal of Judges, $50 \mathrm{~J}$. AM. JuD. Soc'y 64 (x966).

${ }^{80}$ Hearings on Judicial Fitness Before the Subcomm. on Improvements In Judicial Machinery of the Senate Comm. on the Judiciary, 8gth Cong., 2d Sess., pt. I, at 34 (rg66) [hereinafter cited as 1966 Hearings, pt. I].

${ }^{\circ} \mathrm{J}$. Borkin, The Corrupt Judge (1962).

${ }^{4}$ N.Y. Times, Dec. 9, rg62, $\$$ VII (Book Review), at 26.

42 See, e.g., S. I6I3, 88th Cong., Ist Sess. (I963).

${ }^{43}$ See 1969 Hearings, supra note 4, at 2 (remarks of Senator Tydings): "The one instance of Judicial Conference action-a resolution forbidding judges to be directors, officers or employees of commercial corporations-came only after a series of prize winning press articles . . . "
} 
action." ${ }^{\text {44 }}$ As the result of an investigation by the Rules Committee, the Senate adopted a resolution requiring limited disclosure of assets and income by employees and Senators. A permanent Ethics Committee was created, and following more "unfortunate experiences," both Houses of Congress "had created permanent watchdog committees on ethics and had written ethics codes" Congress took the lead in adopting ethical codes, providing for self-regulation and financial disclosure. ${ }^{46}$ Beginning with the Baker case in 1963 , public attention was kept on the ethics question and the need for reform and self-regulation during the years when the Judicial Reform Act was being studied and drafted for introduction.

Also in 1964 , an ad hoc committee of the Section on Judicial Administration of the American Bar Association, the Committee on Removal and Discipline of Judges, headed by New York Supreme Court Justice Miles F. McDonald, concluded that a constitutional amendment would be necessary to remove article III judges other than by impeachment. Therefore, the committee recommended a constitutional amendment providing for a Court on the Judiciary empowered to initiate removal hearings on order of the Chief Justice. The court was to consist of five judges designated by a majority of the Supreme Court. This recommendation was never acted on, however, due to a bar-sponsored nationwide study of judicial removal, discipline, and compulsory retirement at the state and federal level. ${ }^{47}$

On May 14, 1965, Senator Joseph D. Tydings of Maryland was appointed Chairman of the Subcommittee on Improvements in Judicial Machinery. Bringing in a new staff of attorneys, Senator Tydings initiated a comprehensive study of the federal judiciary and the administration of justice. With increasing attention being focused on the problems of state and federal courts, and with increasing activity by the states in adopting constitutional amendments patterned after the New York and California plans, the Senator announced on the Senate floor on October 15 , 1965, that his subcommittee would begin to study a number of suggested reforms. ${ }^{48}$ Among other things, the Senator announced hearings to be held on the problem of judicial fitness.

Ironically, only two months later, on December 13 , 1965, a bombshell was set off when the Judicial Council of the Tenth Circuit, meeting in special session, took unprecedented action in suspending District Judge Stephen Chandler from all judicial duties. Judge Chandler immediately challenged the action by filing with the Supreme Court a motion for leave to file a petition for a writ of mandamus and/or prohibition directed to the Judicial Council and asking a stay of its order. The litigation, as well as the running dispute between Judge Chandler and the Council, continued until

\footnotetext{
"4 yog Cong. REC. IgI82 ( 1963 ) (remarks of Senator Keating).

45 iog Association of the Bar of the City of New York Special Committee on Congressional Ethics, Congress and the Public Trust 220 (I970).

${ }^{10} \mathrm{Id}$. at 216-2I.

${ }^{47} 1966$ Hearings, pt. I, supra note 39 , at 35 .

${ }^{48}$ III CoNg. REc. 27105-Io (1965).
} 
resolved in a most unfortunate and unsatisfactory manner by the Supreme Court on June I, $1970 .{ }^{49}$ The Chandler case cast a long shadow over the hearings on judicial fitness.

On February I5, I966, the Tydings subcommittee opened its initial session of hearings. The focus was clearly on the "administration of justice" rother than the issue soon to become dominant, "the crisis of confidence"51 in the federal judiciary itself. Yet portentous of things to come, the effects of the Chandler case were clearly visible. Thus, while the main thrust of Senator Tydings' opening remarks was directed toward the growing problems of case backlogs and trial delays, he also noted that "the subcommittee cannot ignore the charade that occurred recently in the western district of Oklahoma ...." attention of the nation a situation that has troubled many observers-including Senators and Congressmen-for a long time."53

Acknowledging that serious constitutional problems were involved, Senator Tydings reopened and invited renewed debate on the question that had lain dormant since the debates over the Sumners Bill. As stated by the Senator:

Impeachment is perhaps the sole method of removal of federal judges that may be constitutionally employed by the Congress, for the principle of an independent judiciary, free from interference by the legislative or executive branches, is central to the concept of a government of separated powers. But this is not to say that impeachment is the only constitutionally permissible method of removing a Federal judge from office. It should be borne in mind that a judge is to serve "during good behavior," while impeachment lies only for bribery, treason, "high crimes and misdemeanors." It may be that the framers of the Constitution intended to permit other methods of removal not inconsistent with the principle of separation of powers .... ${ }^{54}$

The constitutional issue was immediately joined by North Carolina's Senator, Sam Ervin, without question the foremost constitutional authority ever to serve in Congress. The question was simply put by Senator Ervin: "Is there presently an

\footnotetext{
${ }^{\star 0}$ Chandler v. Judicial Council, 398 U.S. 74 (1970).

${ }^{50}{ }_{1966}$ Hearings, pt. I, supra note 39 , at I.

61 1969 Hearings, supra note 4 , at 2.

1966 Hearings, pt. I, stipra note 39 , at 2.

${ }^{\mathrm{E}} \mathrm{Id}$. at 3 .

6l Id. at 4. For arguments supporting theory of constitutionality see Shartel, supra note 20; H.R. Rep. No. 814, 75th Cong., Ist Sess. (1937); H.R. REP. No. 537, 76th Cong., Ist Sess. (1939); H.R. REP. No. 921, 77th Cong., Ist Sess. (I94I). For briefs see 194I Hearings, supra note 30, at 221-28. See also Kramer \& Barron, The Constitutionality of Removal and Mandatory Retirement Procedures for the Federal ludiciary: The Meaning of "During Good Behavior," 35 Geo. Wash. L. Rev. 455 (1967); Comment, Removal of Federal Judges: New Alternatives to an Old Problem: Chandler v. Judicial Council of The Tenth Circuit, 13 U.C.L.A.L. REv. 1385 (1966); Comment, Removal of Federal Judges-Alternative to Impeachment, 20 VAND. L. REV. 723 (I967). For the Nixon Administration position on the constitutional issue, sce testimony of William H. Rehnquist, Asst. Att'y. Gen., Hearings on S. 1506, The Tudicial Reform Act, and Related Bills Before the Subcomm. on Improvements in Judicial Machinery of the Senate Comm. on the 7udiciary, 9Ist Cong., 2d Sess. 5 (April 9, r970) (unpublished) [hereinafter cited as April 9, 1970 Hearings].
} 
alternative to impeachment for the removal of federal judges?"5s The answer, said the Senator, is "emphatically 'No." "'56 Not closing the door, however, to possible need for an alternative, the Senator suggested a constitutional amendment might be in order. Following a recess in the hearings, during which time an extensive staff study was made of various state procedures for dealing with judicial retirement and removal with attention finally focusing on New York and California, hearings were resumed in New York, San Francisco, and Los Angeles, as well as Washington, with testimony received from numerous state and federal officials, members of the bar, and other interested parties. The year 1967 was spent "in discussion, research and analysis" ${ }^{37}$ which resulted in the final drafting of the Judicial Reform Act, introduced on February 28, I968, as Senate Bill 3055, title I of which contained a provision for a National Commission on Judicial Disabilities and Tenure, "patterned after the California Commission on Judicial Qualifications."158

Hearings were resumed on April 23, I968, and numerous witnesses were called to testify on all of its provisions, with the greatest interest on title I. Noting that prior to these hearings copies were sent to all federal judges and a broad selection of lawyers, Senator Tydings acknowledged that there had been "praise and criticism" and called for a "spirited dialog on this legislation in the hope that a modified and improved bill can be fashioned for introduction early in the 9ist Congress." Tydings announced that he was "not wedded to every particular of the Judicial Reform Act," only minor amendments were made when reintroduced in this the Ninety-first Congress. ${ }^{61}$

While the hearings by the Tydings subcommittee continued to draw increasing interest within the legal profession and judicial system, the series of events that would make judicial reform a national issue were set off on June 26 , I968, with the nomination of Associate Justice Abe Fortas to be Chief Justice of the United States. The explosive controversy ignited by the Fortas fight, the charges of unethical conduct which preceded his failure of confirmation, ${ }^{62}$ and the more serious charges which subsequently led to his resignation on May $16, \mathrm{I} 96 \mathrm{~g}^{63},{ }^{63}$ unleased a chain of consequences which has yet to run its course and which has gravely damaged the image

${ }^{55} 1966$ Hearings, pt. I, supra note 39 , at 5.

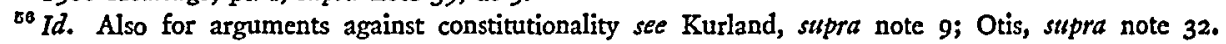
See also Comment, Judicial Responsibility, 21 Rutgers L. REv. 53 (I966); Comment, The Chandler Incident and Problems of Judicial Removal, Ig Stan. L. Rev. 448 (I967); Chandler v. Judicial Council, 398 U.S. 74, I29 (Black and Douglas, J., dissenting opinions).

${ }^{57} 1969$ Hearings, supra note 4 , at $\mathrm{I}$.

${ }^{58} 1968$ Hearings, supra note I8, at 28.

${ }^{50} \mathrm{Id}$.

${ }^{B 0} \mathrm{Id}$.

${ }^{\text {ax Id. }}$.

${ }^{02}$ For review of the Fortas fight see 1968 Cong. Q. Almanac 513-40. See also Hearings on the Nomination of Abe Fortas, of Tenn., to be Chief Justice of the United States, Before the Senate Comm. on the Jutdiciary, goth Cong., 2d Sess. (I968).

${ }^{63}$ For review of events leading up to the Fortas resignation see 1969 Cong. Q. Alaranac 136-39. 
of the federal judiciary. Adding fuel to the fire, the Fortas controversy coincided with a groundswell of widespread criticism of the Warren Court. ${ }^{64}$ As evidence of this atmosphere, the winning candidate for President of the United States in Ig68 made the Supreme Court an issue and promised to appoint a "strict constructionist" rather than a "judicial activist" if elected."

The effect of the Fortas case on consideration of the Judicial Reform Act was clearly evident when the Tydings subcommittee resumed hearings in the Ninetyfirst Congress. Gone were the expressions of confidence in and reverence for the federal judiciary which had always carefully preceded the remarks of Senators and testimony of witnesses in the past. The remarks were now sharply critical of the "judiciary's failure to keep its house in order"66 and the emphasis was on the "crisis of confidence, a crisis that threatens to gravely impair its strength and its effectiveness." Ev Even gone were the traditional pledges of allegiance to the concept of an independent judiciary. The new tone and focus of the hearings were expressed by Senator Tydings:

An exaggerated view of judicial independence, and the customary inertia of the judiciary have deterred the judiciary from meaningful attempts to codify standards of judicial conduct or to require the disclosure of extra-judicial activity and compensation.

As an independent branch of the Federal Government holding all Federal judicial power under the Constitution, the judiciary has inherent power to police and regulate itself. The Judicial Reform Act does no more than create machinery that will assist the judicial branch to exercise effectively its power. In my mind, it represents an idea whose time has come. ${ }^{68}$

On June 3, I969, hearings began on the nomination of Warren E. Burger to be Chief Justice of the United States. Senator Tydings elicited favorable responses from the nominee on a number of provisions of the Judicial Reform Act. ${ }^{69}$ More interesting was the response of the nominee in the following colloquy concerning the Judicial Commission on Tenure and Disability:

\footnotetext{
ot See A. Bickex, The Supreme Court and the Idea of Progress (I970); Hearings on the Supreme Court Before the Subcomm. on Separation of Powers of the Senate Comm. on the Judiciary, goth Cong., 2d Sess. (1968); Hearings on Controlling Crime Through More Effective Law Enforcement Before the Subcomm. on Criminal Laws and Procedures of the Senate Comm. on the Judiciary, goth Cong., Ist Sess. (1967); S. REp. No. ro97, 9oth Cong., 2d Sess. (I968) (Safe Streets Act). See also Hearings on Nomination of Abe Fortas, of Tenn., to be Chief Justice of the United States Before the Senate Comm. on the Judiciary, goth Cong., 2d Sess., pt. I (Ig68); S. Exec. Rep. No. 8, 9oth Cong., 2d Sess. (Ig68) (individual views of Senators Eastland, Ervin, McClellan, and Thurmond).

${ }^{\circ 5}$ See, e.g., N.Y. Times, Jan. 2I, I970, at 44, col. 2: "Judge G. Harrold Carswell . . has a virtually unblemished record as the type of 'strict constructionist' that Mr. Nixon promised to appoint when he campaigned for the Presidency."

${ }^{\circ 0} \mathrm{Ig} 9 \mathrm{~g}$ Hearings, supra note 4 , at 2.

${ }^{\mathrm{or}} \mathrm{Id}$.

${ }^{\text {os } I d . ~ a t ~ 2-3 . ~}$

${ }^{\circ}$ Hearings on the Nomination of Warren E. Burger to be Chief Justice of the United States Before the Senate Comm. on the Judiciary, 91st Cong., Ist Sess. 8-12 (1969).
} 
Senator Tydings. Do you think that such a mechanism within the judicial system itself, within the judiciary, as I described it, would interfere with the independence of the judiciary?

Judge Burger. I do not. I do not.

Senator Tydings. As I described my judicial reform proposal, do you feel it would be consistent with the separation of powers doctrine of the Constitution? ator.70

Judge Burger. It has never occurred to me that there is any conflict there, Sen-

Expressing his opinion that section $33^{1}$ of title 18 of the United States Code vested self-regulating power in the judicial councils, the nominee stated, "But if they do not perform it under that machinery, then some other machinery is essential."11 It is interesting, if not unusual, that it apparently did not occur to the nominee that a constitutional issue was involved with mandatory retirement of federal judges, with self-discipline under section 33, or with the Commission on Tenure and Disability. ${ }^{22}$

On June 1o, rg6g, reacting again to the Fortas controversy, as they had earlier reacted to the Landauer article in the Wall Street Journal, the Judicial Conference adopted a resolution providing guidelines for extra-judicial activities and requiring limited financial disclosure. ${ }^{73}$ Unlike the resolution of October 1963 , this one did not include Supreme Court Justices. The subsequent failure of the Supreme Court to adopt a similar resolution drew sharp criticism from all sides. ${ }^{74}$ The Conference action received generally a favorable reaction, although many called for stronger measures. The Washington Post, in an editorial of June 13 , I969, said the action "has gone a long way in buttressing integrity in the courts. ... Nevertheless, it is more of a beginning than an end." The Post concluded: "The most hopeful approach, we think, is to be found in Senator Tydings's bill to create a Commission on Disabilities and Tenure, with power to investigate the conduct of misbehaving or incapacitated judges."75

With fallout from the Fortas resignation continuing, on July I4, Ig6g, Senator Ervin's Subcommittee on Separation of Powers of the Committee on the Judiciary began hearings on the non-judicial activities of Supreme Court Justices and other federal judges, receiving testimony from lawyers, professors, judges, and public officials. ${ }^{76}$ Among these were Dean Acheson, Arthur Goldberg, and Tom Clark. These hearings focused on the proper standards for non-judicial activities by judges in general. Attention was also given to the constitutional problems of ethical self-

\footnotetext{
${ }^{70} I d$. at II.

${ }^{71}$ Id.

${ }^{72} I d$. at II-I2.

${ }^{73}$ Judicial Conference of the United States, Proceedings 42-43 (1969).

"7s See, e.g., Washington Post, June 13, 1969, at A26, cols. I-2 (editorial).

${ }^{78} I d$.

${ }^{78}$ Hearings on Nonjudicial Activities of Supreme Coutrt Justices and Other Federal Judges Before the Subcomm. on Separation of Powers of the Senate Comm. on the Judiciary, grst Cong., Ist Scss. (I969) (unpublished).
} 
regulation by the judiciary, with special consideration given to the authority of the Judicial Conference and judicial councils to adopt and enforce rules and regulations governing the conduct and activities of federal judges. Fuel was added to fire in October with the disclosure, after hearings before a three-judge panel in the Southern Louisiana Gas Rate Cases, that two members of the panel held substantial stock, individually and/or as trustees, in several of the corporations appearing as parties in the case. The judges involved first notified counsel of record of their holdings and gave them until October $2 \mathrm{I}$ to request disqualification. However, amid growing criticism and controversy, the judges voluntarily disqualified themselves four days ahead of the deadline. ${ }^{77}$

But it was on July II, 1969 , that the Tydings bill received the first real break, virtually unnoticed and from an unexpected source. On that day Attorney General Mitchell submitted to Congress, in the form of a legislative proposal, the District of Columbia Court Reorganization Act of 1969 , providing in title I, chapter 15, a District of Columbia Commission on Judicial Disabilities and Tenure. ${ }^{78}$ This proposal was introduced on July II, as Senate Bill 260I. On July I5, Ig6g, Dick Kleindienst, Deputy Attorney General, appearing before joint hearings held by the 'Tydings' District of Columbia Committee and the Tydings' Judiciary Subcommittee on Improvements in Judicial Machinery, testified as follows:

As a constant check on the quality of judicial service, we propose a Commission of Disabilities and Tenure. This commission is similar in many respects to the one proposed by Senator Tydings in S. I214. Like S. I214, it finds its precedent in the laws of New York and California. It is recommended by the American Bar Association and by our own Judicial Council Committee on the Administration of Justice.

We urge this committee to look with care at our proposed Commission on Disabilities and Tenure. It is more specific and detailed than S. 1214 and it offers such important adjuncts as the power to suspend and automatic removal upon conviction of a felony. ${ }^{79}$

While the removal commission provided in the District of Columbia Court Reorganization Act, later to become known as the D.C. Crime Bill, did not apply to article III courts, official administration support for the concept of such a commission within the federal system, accompanied by favorable references to the Judicial Reform Act, must be regarded as an important event in its political and legislative history. ${ }^{80}$ Subsequent to these events, this administration support would

\footnotetext{
${ }^{77}$ Sce Mackenzie, Public Is Starting to Judge the Judges, Washington Post, Oct. 26, I969, at B3, col. 2 (continuation from $\mathrm{BI}$, col. I).

${ }^{78}$ Hearings on S. $260 \mathrm{r}$ and Related Bills, Reorganization of the District of Columbia Couts, Before the Senate Comm. on the District of Columbia and the Subcomm. on Improvements in Tudicial Machinery of the Senate Comm. on the Judiciary, 9ist Cong., Ist Sess., pt. 3, at I139 (1969).

${ }^{70} \mathrm{ld}$. at $\mathrm{I} 152$.

${ }^{80}$ See Hearings on the Judicial Conference of the United States and the Judicial Councils of the Circuits, and the Independence of Federal Judges Before the Subcomm. on Separation of Powers of the Senate Comm. on the Judiciary, 9Ist Cong., 2d Sess. 19 (April 7, 1970) (unpublished) [hereinafter cited as
} 
be expanded to specifically include the Judicial Reform Act. It should be noted that the Senate Judiciary Committee requested an opinion from Attorney General Ramsey Clark on Senate Bill 3054 on March 6, 1968, that no reply was received, and that no administration spokesman ever appeared to testify at any of the hearings held on the Act during the Johnson administration.

At the annual meeting of the American Bar Association in Dallas, August II-13, I969, the report of the Standing Committee on Judicial Selection, Tenure, and Compensation recommended the following resolution: "Resolved, that the American Bar Association support the enactment of Title I of the Judicial Reform Act (Senate Bill I506)."

This committee joins with the sponsors of the Judicial Act, however, in the belief that Congress has the power to provide by legislation for the removal of judges who do not meet the standards of good behavior. ${ }^{82}$

Reflecting concern over the Fortas affair, the committee report concluded that 'Senator Tydings' bill will strengthen the judicial system and increase public confidence in the federal judiciary." ${ }^{83}$ However, on August 13 the House of Delegates deferred action on the resolution. ${ }^{84}$ On the same day the House of Delegates adopted a new Code of Professional Responsibility for lawyers, replacing the old canons and thus completing action begun on August I4, I964, with the appointment of a Special Committee on Evaluation of Ethical Standards. ${ }^{85}$ Likewise in August, President Bernard Segal appointed a special committee on Standards of Judicial Conduct to consider revision of the existing Canons of Judicial Ethics. ${ }^{83}$

On September 16 , $x 969$, hearings began on the nomination of Clement Haynsworth to be an Associate Justice of the Supreme Court. With the "politics of ethics" at high tide, an atmosphere of vendetta pervaded Washington in the wake of the Fortas resignation. And with the replacement of Chief Justice Warren with Chief Justice Burger, a seat now representing a swing vote on many volatile social, political, and economic issues ${ }^{87}$ this nomination too became embroiled in bitter controversy with charges of "insensitivity" to the canons of ethics and the disqualification

Apr. 7, 1970 Hearings]: "Worse yet, this commission would serve as an arguable precedent for instituting the same kind of hazing commission' for the entire Federal judiciary" (remarks of Senator Ervin).

${ }^{81} 94$ A.B.A. REP. 469 (I969).

${ }^{82}$ Id. at 473 .

${ }^{83} I d$.

8s Id. at 396-97.

${ }^{86}$ For canons see id. at 729-96; For adoption see id. at 389 .

${ }^{80}$ Hearings on S. 1506 , the Judicial Reform Act, and Related Bills Before the Subcomm. on Improvements In Judicial Machinery of the Senate Comm. on the Judiciary, 9rst Cong., rst Sess. I73 (Nov. 24, 1969) (unpublished) [hereinafter cited as Nov. 24, 1969 Hearings].

${ }^{87} \mathrm{Mr}$. Justice Fortas and Mr. Chief Justice Warren voted with the majority in practically all of the closely divided (5-4 and 6-3) controversial decisions of the Warren Court from 1965 involving criminal laws, labor law, subversive activities, obscenity, and civil rights. With the retirement of Chief Justice Warren and the resignation of Mr. Justice Fortas, the position of the Warren Court in all of these cases was placed in potential jeopardy, in view of the President's announced intention to appoint a "strict constructionist." 
statute. ${ }^{88}$ Failure to confirm the Haynsworth nomination, ${ }^{89}$ followed by failure to confirm Carswell,90 followed by charges against Justice Douglas and an impeachment investigation by the House Judiciary Committee, ${ }^{91}$ have continually kept the federal courts in the vortex of controversy from Ig68 to present. In November I969, yielding apparently to opposition and complaints from federal judges, the Judicial Conference suspended the resolution of June Io and instead required only that compensation exceeding \$roo be reported to a panel of three judges appointed by the Chief Justice, the report to be kept confidential. ${ }^{92}$ The Conference cited as reasons for its action lack of standards to guide the councils, the pending American Bar Association study of judicial ethics, and a lack of statutory authority.$^{83}$ Reaction to the Conference action was sharply critical. Senator Tydings, announcing new hearings, immediately attacked the Conference action as reflecting "a myopia characterized by an inability to perceive the threat to the institutional integrity of the federal judicial system"94 posed by recent scandals. The Washington Post, in an editorial on November 4, Ig6g, criticized the Conference action as a "setback" for judicial reform and a "retreat from the bold stand taken under the prodding of former Chief Justice Warren." the recommendation of the Committee on Court Administration approving title I of Senate Bill 1506, even though action on it was deferred, and consideration by the Conference of other titles of the Judicial Reform Act. ${ }^{98}$

In the wake of unfavorable public reaction to the Conference's repeal of the June Io resolution, Chief Justice Burger appointed an Interim Advisory Committee on Judicial Activities, to "be available for consultations with, and to give advisory opinions to the several circuit judicial councils and to individual federal judges, upon request, about off-bench activities by judges." 97 On January 26,1970 , the Interim Advisory Committee issued its first five advisory opinions on off-bench activities of federal judges. The Committee announced that it would use the American Bar Association's present Canons of Judicial Ethics as a base for promulgating its advisory opinions until the new code was completed. ${ }^{98}$

On March 16, I970, the Judicial Conference adopted a resolution requiring all

\footnotetext{
${ }^{88}$ See Hearings on Nomination of Clement F. Haynsworth, Jr., of South Carolina to be Associate Justice of the Stipreme Court of the United States Before the Senate Comm. on the Judiciary, 91st Cong., Ist Sess. (1969); S. Exec. Rep. No. 9I-I2, goth Cong., rst Sess. (I969).

${ }^{80}$ For vote on Haynsworth nomination see II5 CoNG. REc. S. 14886 (daily ed. Nov. 2I, I969).

${ }^{\circ 0}$ See Hearing on Nomination of George Harrold Carswell to be Associate Justice of the Supreme Court of the United States, Before the Senate Committee on the Judiciary, 9rst Cong., 2d Sess. (1970). For vote on nomination see II6 Cong. Rec. S5307 (daily ed. April 8, I970).

${ }^{01}$ See I16 Cong. REC. H7933 (daily ed. August 6, r970) (remarks of Congressman Ford).

${ }^{23}$ Judicial Conference of the United States, Proceendings 50-52 (ig69).

${ }^{93}$ Nov. 24, 1969 Hearings, supra note 85, at $167-219$ (testimony of Judge Ainsworth).

ot Washington Post, Nov. 8, I969, at A7, col. I.

${ }^{05}$ Id., Nov. 4, 1969, at AI8, col. I (editorial).

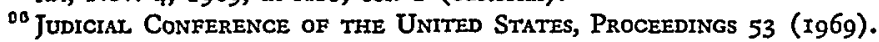

${ }^{07}$ Administrative Office of the U.S. Courts, Press Release, Jan. 26, I970.

${ }^{\circ 8}$ Id.
} 
federal judges to report compensation for extra-judicial activities, positions held in business or other organizations, and participation in cases where any financial interest was held. The Committee further recommended that no other financial reporting be required pending completion of the report of the American Bar Association on the revision of the standards of judicial conduct. ${ }^{29}$

In early 1970, the Judicial Reform Act received official support from the American Bar Association. At its mid-year meeting in Atlanta, February 23-24, the Committee on Judicial Selection, Tenure, and Compensation adopted a resolution described by Chairman Vorhees as "a fairly strong recommendation of support of the legislation that is before the committee."100 The House of Delegates, following a speech by Senator Tydings, adopted overwhelmingly a similar resolution calling for "enactment of federal legislation establishing a procedure for the removal of federal judges who fail to meet accepted standards of the constitutional requirement of good behavior." 101 Perhaps more important than the ABA resolution was a statement by Deputy Attorney General Kleindienst in his remarks prior to a debate on the D.C. Crime Bill. Referring to the Tydings proposal, Kleindienst remarked:

Although we have not yet presented our position to the Congress, we will in the near furure. We commend his effort and his activity and his diligence in this area, and like you, as the result of the vote you took this morning, we are hopeful that the Congress will enact this into legislation this year. ${ }^{102}$

Administration support for the Judicial Reform Act was reiterated on April 9, 1970, when Assistant Attorney General Bill Rehnquist testified before the Tydings subcommittee in support of its constitutionality and endorsed the earlier Kleindienst statement. ${ }^{103}$ It is of further interest that Associate Justice Blackmun, as was the case with Chief Justice Burger, apparently saw no constitutional problems with the Judicial Reform Act when testifying at Senate Judiciary Committee hearings on his nomination. As stated by the nominee:

What I am saying is that there are ways and means in my view on the statute books today. ... That to which Senator Tydings refers is an alternative. Perhaps it is a better way, but again I come to where I started, that I see no great danger of interfering with the independence of the judiciary in such a provision. ${ }^{104}$

With the momentum behind the Act building, so has opposition within the federal judiciary, the bar, and the Senate. ${ }^{105}$ For proponents of the legislation, the growing interest and opposition of Senator Sam Ervin of North Carolina must loom

\footnotetext{
${ }^{90}$ Judicial Conference of the United States, Proceedings 6-9 (Mar. I6-17, 1970).

${ }^{100}$ April 9, 1970 Hearings, supra note 54, at 13.

101 AM. B. News, Mar. 1970.

102 April 9, 1970 Hearings, supra note 54, at II.

${ }^{108} I d$.

106 Hearings on Nomination of Harry A. Blackmun to be Associate Iustice, Before the Scnate Comm. on the Judiciary, 91st Cong., $2 \mathrm{~d}$ Sess. $\mathrm{xx}$ (1970).

${ }^{105}$ April 7, 1970 Hearings, supra note 80.
} 
larger than any occurrence since consideration began. The respect within the Senate for Ervin's opinion on the law, the courts, and the Constitution crosses party lines and political philosophies. On April 7, 1970, Ervin's Subcommittee on Separation of Powers commenced hearings on "The Judicial Conference of the United States, the Judicial Councils of the Circuits, and the Independence of Federal Judges." Ervin's opening remarks reveal his hardening attitude toward the judicial removal commissions provided in the D.C. Crime Bill and the Judicial Reform Act. As the Senator stated, "I am not convinced that conditions in the federal courts merit such bone-crushing legislation, not for the District of Columbia, and not for the federal courts at large."10e As these hearings reflected growing opposition to the Act, it was obvious that the counterattack had begun.

The Act received another setback on April 28, 1970, when the Committee on the Federal Courts of the Association of the Bar of the City of New York reported: "We disapprove passage of title I of the bill at this time."107 Noting the "difficulty and seriousness of the constitutional question posed by this bill . . .,"108 the report cautioned: "That public confidence may be shaken by recent sensational events is significant, but Congress should be particularly careful in formulating a response in this sort of atmosphere on an issue of such immense and continued importance."100 The report further noted that the Chandler case, "already argued in the Supreme Court of the United States may resolve at least some of the uncertainties."110 Unfortunately, the Chandler decision came down on June I, I970, and resolved little. As noted by Justice Douglas in dissent, "The case is ripe for decision and we have no excuse for declining to decide it."111 The committee report also contained an analysis of each title and suggested a number of changes.

On June I, I970, Senator Ervin sent a letter to all federal district judges asking their opinion concerning the legislation. The responses were overwhelmingly critical, with most expressing fear that the commission would constitute a threat to the independence of the federal judiciary. ${ }^{112}$ In June 1970 , the American Bar Association Special Committee on Standards of Conduct released its preliminary statement and announced public hearings which were held on August 8 at the annual meeting in St. Louis. ${ }^{113}$ The final draft is scheduled to be submitted for adoption in 1970 .

Yet despite growing opposition, thus far in the Ninety-first Congress several provisions contained in the Act have passed the Senate only to be rejected by the

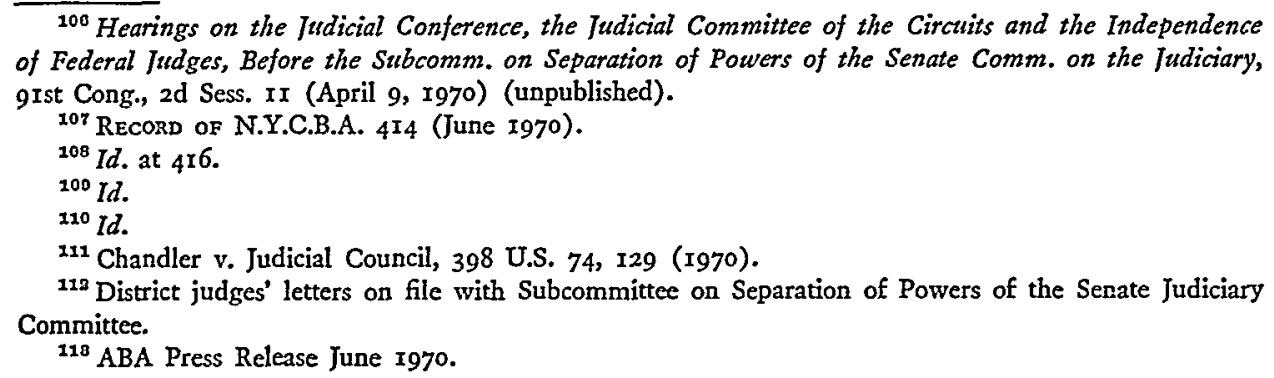


House. Senate Bill I508, providing for retirement of federal judges after twenty years at any age passed the Senate on October 29, $1969 .{ }^{114}$ It was amended by the House Judiciary Committee to provide for retirement after twenty years and age sixty but was killed on the floor. ${ }^{115}$ Likewise, Senate Bill 952, the "Omnibus Judgeship Bill," as passed the Senate, provided for court administrators and gave subpoena power to the judicial councils in dealing with disability retirements under sections 332 and 372 (a) of title 28 of the United States Code. ${ }^{116}$ But more important, the principle of a judicial removal commission in the federal system was approved in title I of the D.C. Crime Bill, enacted by Congress and signed into law as Public Law 9x-358. Senator Ervin noted that "this commission would serve as an arguable precedent for instituting the same kind of hazing commission for the entire federal judiciary." 1117

\section{III}

\section{Titue I: Commission on Disabilittes and Tenure}

Having considered the evolution of the concept of judicial removal by means other than impeachment; the events which obviously influenced its authors in the process of drafting; the further circumstances which focused national attention on judicial ethics, providing a windfall of interest and support for the Judicial Reform Act; and assuming its constitutionality, consideration of title $I$ is in order.

In a nutshell, title I of Senate Bill I506 provides for a Commission on Judicial Disabilities and Tenure, composed of five federal judges, appointed by the Chief Justice to staggered four year terms. The Commission is empowered, upon complaint of any person, to investigate, charge, try, and recommend removal of any article III judge for "willful misconduct in office or willful and persistent failure to perform his official duties" or "intentional failure" to file reports required by title IV of the act. Upon recommendation of removal by the Commission, the judge is suspended from office pending review by the Judicial Conference. If the Commission recommendation is accepted by the Judicial Conference, certification thereof is made to the President, the judge is removed, and a successor appointed. The Supreme Court, on petition of the aggrieved judge "may review by writ of certiorari" the certification of the Judicial Conference. The Conference shall stay its certification to the President "pending review in the Supreme Court" or until "time for seeking such review has passed without the filing of a petition for the writ of certiorari." Using the same procedure, the Commission is authorized to involuntarily retire any judge upon a determination that he has "a physical or mental disability seriously interfering with the performance by him of one or more of his critical duties and that the disability

\footnotetext{
114 II5 Cong. Rec. Si3396 (daily ed. Oct. 29, r969).

${ }^{215}$ II6 Cong. Rec. $\mathrm{H}_{4464}$ (daily ed. May 18, I970).

${ }^{110}$ S. Rep. No. 91-262, 9rst Cong., rst Sess. (1969) (provisions deleted in House).

${ }^{112}$ April 7,1970 Hearings, supra note 80, at 19.
} 
is or is likely to become permanent ...." As further definition of permanent disability the act provides: "Habitual intemperance that seriously interferes with the performance of any of the critical duties of a judge shall be regarded as a permanent disability."

Aside from the constitutional question, one of the first determinations to be made with respect to title $I$ is whether the advocates of a judicial removal commission have established on the face of the record such a compelling need as to justify such a drastic remedy. This writer believes they have not.

Joseph Borkin, noting the need for a study, told the Tydings subcommittee in Ig68:

Maybe we are talking about a problem that does not exist or maybe we are talking about a real problem, but we really do not know. I do not know. ${ }^{118}$

As of this date no survey has been made of the existence or extent of the problem of the "unfit judge." However, a number of studies have been made in recent years on court reform in general and trial delays in particular. None of the findings and recommendations resulting from these suggest that the "unfit judge" is part of the problem.

The thrust of the testimony presented to the Tydings subcommittee indicates a number of things concerning judicial disability and misconduct. First, malfeasance is unknown or nonexistent in the federal judiciary at this time; the likelihood of such is remote and criminal prosecution or impeachment would be sufficient to deal with it. Second, only a handful of judges would be termed "unfit" under the broadest interpretation of misconduct and disability. Third, accepting as fact the vague references to problems with unnamed judges, practically all were caused by the various disabilities of old age and were invariably solved by persuading the offending judge to retire or by other means, as unpleasant and troublesome as it might have been. Finally, most of the problems alleged would fall under the involuntary retirement provision of the bill.

It is interesting to note that the much-heralded California commission has only ordered one judge removed, and that action was overturned by the state Supreme Court. The New York Court on the Judiciary has only been convened three times in its history.

Assuming that the removal commission is constitutional and that a need does exist, the question arises as to whether the definitions of misconduct and disability are so vague as to violate fundamental concepts of due process. This writer believes they are. Mr. Winters of the American Judicature Society noted that the definition of misbehavior "sheds very little additional light on what kinds of conduct are actually subject to discipline."118 Judge Haynsworth acknowledged the definition "may

\footnotetext{
${ }^{118} 1968$ Hearings, supra note 18 , at 103.
}

${ }^{110}$ Id. at IIo. 
involve a due process question of vagueness."120 Judge Craven concluded: "What is good behavior? I suppose no one can answer that authoritatively." of California witnesses were asked, based on their experience: "What is willful misconduct in office?" Since the language in the Act is lifted verbatim from their constitution, ${ }^{122}$ their responses were interesting. Mr. Frankel, Executive Secretary of the California commission, after groping for an answer, concluded that "the nine members of the commission have a certain discretion, and in certain cases it comes down to their own interpretation of what is willful misconduct in office." ${ }^{123} \mathrm{Mr}$. Schramm, a member of the commission, gave a more direct answer: "No one knows, sir. No one knows what constitutes willful misconduct."124 Mr. Swig, lay member of the commission, responded, "I've never seen a definition but I suppose it is action so wrongful as to render this judge unfit to hold office."125 Mr. Neeley, chairman of the commission answered: "I would hate to definitively define willful misconduct .... It is hard to put your finger on just what it would be."126 Judge Murray of the Superior Court responded: "[I] have had no personal contact ever with such a charge being leveled against a judge, and never heard of it .... I am not sure what the draftsman of that legislation had in mind."127

Yet several federal judges suggested the definition could be "hammered out by experience"128 or "defined in the course of time."129 Judge Craven suggested a "middle ground between the two extremes, the one being misconduct without the slightest definition, the other being an effort by Congress to define it in great detail so that it is precise and everyone knows what it means as you would in a criminal statute."130

Why shouldn't it be defined so "everyone knows what it means ...."? The language of the bill suggests the required inquiry is in the nature of a criminal proceeding. Numerous witnesses compared it to a criminal trial. Senator Tydings expressed concern that the commission act as "both prosecutor and judge."131 Again referring to the commission in the Act, Senator Tydings noted that "Whatever we decide to call it, it actually is a grand jury ...."132

Reviewing the various kinds of conduct different witnesses believed would or

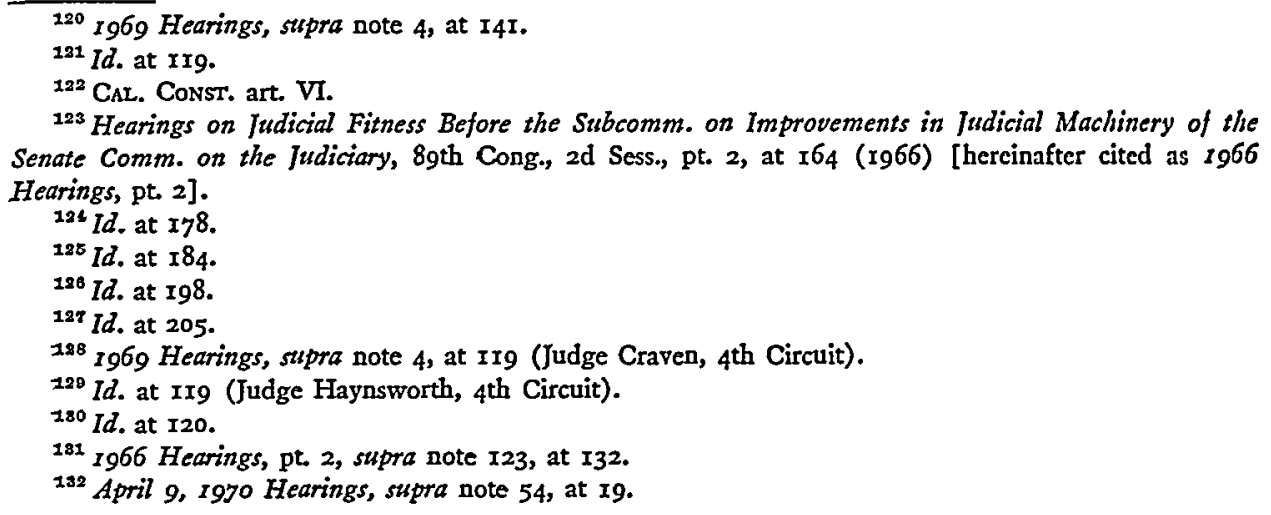


would not be covered by the misconduct or disability, a clearer definition seems imperative. This is especially true when we remember that a judge can be involuntarily retired on concurrence of only three commission members, rather than four as required for removal, and no acceptance by the Judicial Conference is required or appeal to the Supreme Court allowed. For these and other reasons, it can be assumed that every unfit judge will be proceeded against under the disability rather than removal provisions whenever possible.

Do the procedures provided by the bill afford the accused judge due process? This writer believes they do not. The Commission can undertake an investigation "upon complaint, formal or informal, of any person." The complaint should be required to be in writing and sworn to. Immediately upon receipt, a copy should be forwarded to the accused judge. The judge should be notified of any decision to undertake an investigation of the matter. The Commission is only required to give the judge notice of a hearing thirty days in advance and the "nature of the matters under inquiry." The judge is entitled to more. The Commission has decided that the complaint raises sufficient questions to justify an investigation. On the basis of the investigation the Commission has decided to bring the judge to trial. No matter what we call it, this is not an inquiry but a trial at which the judge's job, career, and reputation are in jeopardy. These are not "matters under inquiry" in any real sense of the words, but charges, which if substantiated by the same body making them, could result in removal or involuntary retirement without review or appeal. As noted by Mr. Voorhees of the ABA, "[O]nce you have gone that far the fat is in the fire, and the judge is accused, he has been brought before the commission and the hearing is on." Earl Gray of the ABA described the Commission as determining the "judicial life and judicial death of all of the federal judges . . .."133

If this bill is enacted and this procedure used, the judge should be entitled to a formal, written bill of particulars stating exactly what the charges are and the facts alleged in support thereof, a list of all witnesses to be called, and records to be offered in evidence by the Commission, as well as a statement of what is expected to be proven by each. The judge should be afforded as a matter of right the use of depositions, interrogatories, or any other means of discovery available to the Commission. He also should be afforded as a matter of right the subpoena power. Since the Commission is financing the investigation and prosecution, the judge should be allowed reasonable expenses and attorney fees required for his defense. The accused judge should not be required to stand trial by surprise or endure a fishing expedition by the Commission. Nor should the judge be required to stand trial in Washington, possibly hundreds or thousands of miles from his home, at a place inconvenient to attorneys and witnesses needed for his defense, and remote from the records that might be required in the course of the proceedings. He should be entitled

\footnotetext{
${ }^{288}$ Id. at 2r.
} 
to his day in court in his district or at the federal courthouse nearest the site where the facts giving rise to the complaint allegedly are based.

What rules of procedure and evidence will the accused judge be required to cope with if this bill passes? We do not know. The Conference is empowered to make up the rules of evidence and both it and the Commission are authorized to adopt their own procedures. Thus, the two make up the rules, as well as serving as prosecutor, judge, jury, and appellate court.

Another objection is the secret nature of the proceedings. It is somehow suggested that the secret trial will protect the judge and enhance public confidence in the courts. There is no reason to believe that the complainants or the press will honor such an arrangement. The New York Times recently published a privileged grand jury report involving several prominent public figures. Confidential and classified reports and information are constantly being leaked to and published by the Washington press. That a judge of southern ancestry and conservative philosophy could receive fair treatment from the national news media while on trial in Washington is highly questionable. Note the nominations of Parker, Haynsworth, and Carswell to be Associate Justices of the Supreme Court. The idea that a secret proceeding will enhance public confidence is not only suspect on its face but is refuted by the harsh criticism of the manner in which the Fortas resignation was handled and the public demands that all of the facts be made known. The idea of a secret trial is repugnant to our system of justice and denies the public's right to know. In any event, the accused judge should be entitled to demand that the proceedings be made public as soon as the complaint is filed. He should not be subjected to Star Chamber proceedings. Most important, the procedure for involuntary retirement should be the same as for removal, with concurrence of four commission members, acceptance by the Judicial Conference, and review by the Supreme Court required.

The provision for suspension of the judge following a recommendation of removal should be struck from the bill. The provision authorizing the Judicial Conference to farm out the responsibility for reviewing the recommendation of the Commission and receiving additional evidence or briefs should be deleted. The Conference is charged en banc with responsibilities for accepting, rejecting, modifying, or remanding the recommendation of the Commission, which should receive the full attention of and review by each member thereof, sitting en banc. Where the bill provides that the Supreme Court "may" review the certification of the Conference, it should be changed to "shall." The refusal of the Supreme Court to meet the issues raised in the Chandler case make this mandate all the more compelling.

The bill should set forth the weight of evidence required to sustain the recommendation of the Commission when reviewed by the Conference and appealed to the Supreme Court. Furthermore, the power to appoint members of the Commission should not be vested exclusively in the Chief Justice, if at all. The power 
and burdens of that office are too great now. His actions will be suspect and subject to attack by those who do not share his judicial philosophy. And while the present Chief Justice commands great confidence and respect, we cannot know the character, the mind, or motives of those who will hold that office in the future.

If such legislation is to be enacted, then Supreme Court Justices should be subject to removal and retirement under the same procedures. They hold their life tenure under the same provision of the Constitution as does a federal district judge. They are subject to the same impeachment procedure for "high crimes and misdemeanors" and should be subject to removal or retirement in the same manner, notwithstanding arguments that constitutional questions arise with respect to one and not the other. As a matter of policy, it would be strange indeed to exclude from the Act the very court that has been the center of all the controversy and the justices whose conduct has given rise to public demands for legislation in the nature of the Judicial Reform Act in the first place.

Finally, more disturbing than the provisions of the bill itself are the explanations of the proponents as to how it is expected to work. For the strongest argument advanced in support of the bill is not that unfit judges will be removed or retired but rather will be forced to resign or voluntarily retire under the threat of accusation and trial, with the accompanying ordeal to the judge, his family, and friends. As suggested by Mr. Segal of the American Bar Association: "as occurred in California, if the thing is private and confidential, it will result, as it did there, in 26 cases in judges voluntarily resigning or retiring, rather than undergoing the consequent publicity."134 This argument was asserted again and again. One immediate result of that testimony was a cloud of suspicion cast over every California judge who retired during the period covered. And if this Commission operates the same way, every judge who elects to retire or resign for whatever reason will have no way to prove that such was not prompted by fear of exposure for wrongdoing or disability.

But the greatest value of such a Commission, according to its advocates, lies not in the judges removed or retired, or even in the judges forced to resign or retire, but rather in the fact every judge will in effect know that his actions are being observed. Thus, according to the proponents, even where the conduct of the judge would not justify action by the Commission, he can be called to the carpet, admonished, and straightened out before his behavior gets him into real trouble. Mr. Segal has suggested that "a commission can catch him up on the little errors he makes before they accumulate and multiply into bigger errors."135 For example, a judge in California who "regularly came in late"136 and another who called "lengthy recesses"137

\footnotetext{
${ }^{136} 1966$ Hearings, pt. 1 , supra note 39, at 45. Apparently the original source for much asserted allegation concerning 26 forced retirements in California is Burke, The California Story, 48 J. AMs. Jud. Soc'r $170-71$ (1965).

${ }_{135}$ Ig66 Hearings, pt. I, supra note 39 , at 45.

${ }^{130} \mathrm{Id}$. at 44 .

${ }^{187} I d$.
} 
were taken to task. Thus, "we anticipate in 99 per cent of the cases, just like in California, you would not even have the formal hearing."138

\section{IV}

\section{ConCLUSION}

With respect to title I and the Commission on Judicial Removal and Tenure, this writer adopts the conclusion of Senator Ervin of North Carolina:

I am not convinced that conditions in the Federal Courts merit such bone-crushing legislation. . . . I have not been persuaded that this legislation is constitutional. I have serious reservations about such a commission's capacity for fairness and its ability to refrain from exerting improper influence on judges. To me, the duty of a Federal judge is to decide cases and controversies-not to meddle in the business of his colleagues. ${ }^{139}$

Therefore title I should not be passed in its present form if at all. It is of questionable constitutionality. The need has not been established. The definitions of misconduct and disability, as well as the procedures set forth do not assure the accused substantive and procedural due process. The bill constitutes a threat to the the independence of the federal judiciary and at some future time, as has repeatedly been the case throughout our history, this Commission may be used, perhaps in a time of national crisis, as an instrument to purge the courts for political purposes on the basis of judicial philosophy.

\footnotetext{
${ }^{138}$ April 9, 1970 Hearings, supra note 54, at 20 (remarks of Senator Tydings).

${ }^{130}$ April 7, 1970 Hearings, stspra note 80, at 20.
} 